\title{
Çŏ̆ulcu Din Ĕ̆itimi ve Din Kültürü ve Ahlak Bilgisi Dersi, Cemil Osmanoğlu, Ankara: Nobel Yayınları, 2016, 322 s.
}

\section{Emre ALTINTAŞ*}

Küreselleşmeyle birlikte dünyanın gündemine giren kavramlardan bir tanesi, hiç şüphesiz "Çok kültürlülük" ve "Çoğulculuk" olmuştur. Günümüz dünyası artık homojen toplum yapılarından oluşmamaktadır. Çok ulus ve kültürlü yeni toplum yapısı beraberinde birçok tartışmayı da getirmiştir. Bu tartışmalardan bir tanesi, çok kültürlü toplumlarda din eğitiminin yeri ve bu eğitimin birçok unsuru barındıran yeni sosyal yapılarda hangi şekillerde verileceğidir. Çok kültürlülük ve çoğulculuk Türkçe din eğitimi literatüründe özellikle 2000'li yıllarla birlikte akademik çalışmalara konu olmaya başlamıştır. ${ }^{1}$ Ancak konunun bir yönüne işaret eden tartışmalar özellikle 1982 Anayasası'nın kabul edilme süreçlerinden beri, din derslerinin statüsü ve toplumun değişik dini inanç ve kültürleri barındırması ekseninde devam etmektedir. Son olarak 2005 senesinde kabul edilen yeni Orta Öğretim Din Kültürü ve Ahlak Bilgisi Dersi Öğretim Programları çoğulculuk meselesine eğilmiştir. "Mezhepler üstü ve dinler arası açılımlı" olduğu iddiasıyla uygulanmaya başlayan bu programın; vadettiği çoğulcu tasarımı ne ölçüde gerçekleştirdiği akademik çalışmalarla ortaya çıkarılabilecek bir olgudur. İşte Cemil Osmanoğlu'nun 2014 yılında bitirdiği doktora tezinin kitap olarak sunulan bu versiyonu adı geçen sorgulamayı yapmayı hedeflemektedir.

Kitap; bir giriş, üç ana bölüm ve sonuç kısmından oluşmaktadır. Giriş (s. 1-24) bölümünde de ele alındı̆̆ı gibi 20. yüzyılda küreselleşmenin tetiklediği en önemli konulardan bir tanesi toplumlarda kültürlerin bir arada olmaya başlaması meselesidir. Zamanla çok kültürlük tartışmalarına zemin hazırlayacak bu süreçte fenomenolojik, dinler arası, diyalojik adıyla yeni din eğitimi anlayışları ortaya çıkmıştır (s. 2). İngiltere, ABD gibi yoğun bir göç dalgasına maruz kalan ülkeler ortaya çıkan yeni din eğitimi durumunun çözümü için değişik modeller geliştirmiştir. Konunun yoğun tartışıldığı İngiltere, neredeyse 50 yıldır kamu okullarında birçok din ve inançtan öğrenciye aynı anda din eğitimi vermeye çalışmaktadır (s.3).

\footnotetext{
* Marmara Üniversitesi Sosyal Bilimler Enstitüsü Doktora Öğrencisi (edepyahu85@gmail.com)

1 Konuya dair ilk ve daha kapsamlı bir çalışma için bkz. Nurullah Altaş, Çok kültürlülük ve Din Eğitimi (Ankara: Nobel Yayınları 2003); Ayrıca konuyla ilgili nitelikli bir derleme çalışma için bkz. Recep Kaymakcan, Çok kültürlülük: Eğitim, Kültür ve Din Eğitimi (İstanbul: DEM Yayınlar1, 2006).
}

DOI: http://dx.doi.org/10.17335/sakaifd.346083

Geliş T. / Received Date: 23/10/2017

Kabul T. / Accepted Date: 29/11/2017 
Konunun Türkiye'yi ilgilendiren kısmı daha farklıdır. Zira 1967'den beri liselerde var olan din dersi zaman zaman tartışma konusu yapılmış olsa da değişik inanç grupları tarafından asıl reaksiyon 1982 anayasasıyla dersin zorunlu hale getirilmesinden sonra gösterilmiştir(s. 6). 1990 senesinde diğer din mensuplarının dersten muaf kılınması ile tartışmalar İslam içi grupların iddialarına yönelmiştir. Özellikle Aleviler dersin "Zorla Sünnileştirme” gayesini taşıdı ğı gerekçesiyle Danıştay ve AİHM'e dava açmışlardır. Tüm bu tartışmaları göz önünde bulunduran Milli Eğitim Bakanlığı 2005'te lise din dersi öğretim programlarının çoğulcu bir anlayışla yeniden kurgulandığını belirtmiştir. Uzmanlarca bu değişiklik önemli bulunmuştur(s. 8). 2010'da güncellenen bu programın çoğulculuk iddiaları ise akademik çalışmalara konu olmadı̆̆ için yazar, son olarak 2012-2013 eğitim yılında uygulamaya konulan yeni DKAB öğretim programlarını; 9-12.sınıf din dersi kitapları özelinde ve çoğulculuk bağlamında ele alarak bu çalışmayı gerçekleştirmiştir (s.20). Araştırmada nitel yöntem kullanılmış, veriler Nvivo 10 programıyla adı geçen ders kitaplarından elde edilmiştir (s. 20).

Birinci bölümde (s.25-55) çoğulluk ve çoğulculuk kavramları detaylı olarak incelenerek çoğulculuk kavramının, çoğulluktan farkı ortaya konulmaya çalışılmıştır. Buna göre çoğulluk (plurality) bir bölgede birbirinden farklı inanç veya görüşün bir arada var olmasıdır (s. 26). Günümüzde daha çok Avrupa merkezli olarak düşünülen bu kavram, aslında köklü bir tarihe sahiptir. Geleneksel çoğulluk olarak adlandırılan bu uzun tarihi mirasta farklı din ve kültürden insanlar bir arada yaşamışlardır (s.27). Küreselleşmeyle birlikte artan her türlü hareketliğin ortaya çıkardığg durum ise modern çoğulluktur ve öncesinden ciddi bir paradigma değişimiyle ayrılır (s. 28-30). Dini çoğulluk da oluşan heterojen toplum yapısından nasibini almıştır. Dini çoğulluk yaşanan tüm süreçlerden etkilenerek farklı dini yorumların, inançların, dinle ilgisiz kesimlerin de içinde kabul edildiği bir arada yaşama tecrübesidir(s.35).

Çoğulculuk (pluralism) ise çoğulluktan farklıdır. Politik, kültürel ve dini açıdan tanımlanan çoğulculuk bu çalışma bağlamında daha çok dini çoğulculuk ekseninde incelenmiştir (s.42-48). Dini hoşgörü, dini kapsayıcılık, dini diyalog gibi alt yapılarla kullanılan bu kavram; çoğulluk ile karıştırılarak da kullanılmaktadır (s. 49-54). Çalışma ise her dini eşit düzeyde görerek aralarındaki farkları yok sayan anlayışı eleştirmekte ve dini çoğulculuğu; "farklı din, inanç ve görüşlerin zenginlik olduğu, eşit düzeyde yaşam şansina sahip oldukları, inancın tüm hallerinin insan özgürlü̈̆̈̈ sayıldı̆̆ı" bir düzlemde anlamaktadır (s. 55). Bu yaklaşımın kapsayıcı ve önemli tarafı, çoğulculuk söylemi çerçevesinde aslında hiçbir inanç mensubunun arzulamadığı dinleri eşitleme anlayışının yerilmesidir. Özellikle John Hick'in Dini Çoğulculuğu tüm dinlerin aynı hakikatin farklı yönlerini aynı derecede temsil ettiklerine ve nihayet dinlerin aynı olduğuna varan bir söylemi içermektedir. Bu yaklaşımın sakıncaları 
ülkemizde dinler arası diyalog tartışmaları ve sonrasında yaşanan hadiseler ekseninde tecrübe edilmiştir.

İkinci bölüm (s. 57-137) çoğulculuğun din eğitimi bağlamında ele alınışını içermektedir. Burada küreselleşen bir dünyada eğitimin işlevleri üzerinde durulmuştur. (s. 58-59) Çoğulcu din eğitimini ortaya çıkaran sebepler (s. 63-68) ele alındıktan sonra konu Türkiye özeline getirilmiştir. Türkiye; günümüzde şehirli ve çok kültürlü bir yapıya bürünmüştür. Değişik dini gruplar arasındaki diyalog zayıftır. İslam içi gruplar, özellikle Alevi ve Sünni vatandaşların bir arada yaşaması din derslerinin çoğulcu bir anlayışla hazırlanmasını gerektirmektedir. Yabancı ülkelerin Türkiye'nin iç işlerine karışma gayretlerinin en çok İslam içi farklı gruplarla ilgili olması meseleyi önemli kılmaktadır. Din derslerini çoğulculuğa iten bir sebep de ülkelerin laik yapılarıdır. Özellikle Türkiye gibi ülkelerde "Zorunlu" statüde bulunan din derslerinin laik bir ortamda nasıl var olacağı sürekli tartışılmıştır. Bu manada din eğitiminin zorunlu kısmının çoğulculuğunun tam olarak sağlanması ( s. 75) yapılan tartışmalara önemli bir katkı sağlayacaktır.

Eserde çoğulcu din eğitiminin tanım ve ilkeleri uluslararası antlaşmalara da yapılan atıflarla zengin şekilde ele alınmıştır (s.75-99). Çoğulcu din eğitimi yaklaşımları arasından en çok öne çıkan Lee'nin sosyal bilimler yaklaşımı ile İngiltere'de kendisine yer bulan fenomenolojik ve yorumlayıcı yaklaşımlar ele alınmıştır ( s.100-115). Burada özellikle 90'lı yıllardan beri tartışılan yorumlayıcı yaklaşım oldukça önemlidir. Robert Jackson'un 2005 yılında “Din Eğitimi: Yorumlayıcı Bir Yaklaşım"2 adıyla Türkçeye çevrilen "Religious Education: An Interpretive Appraoach" 3 isimli eserini merkeze alan yorumlay1c1 yaklaşım, yorumlayıcı etnografik metotlarla gerçekleştirilen ve uzun süreye dayanan devlet destekli Warwick Üniversitesi Projesi'nin neticesinde ortaya çımıştır. Bu yaklaşımın dinlere Avrupa merkezli bakışı eleştirerek Oryantalizm bağlamında Edward Said'e yaptığı atıflar çok önemlidir ( s. 107-108). Jackson'un Türkçeye çevrilen eseri maalesef gerekli ilgiye mazhar olamamıştır.

Çoğulcu din eğitiminin amaç, içerik, yöntem ve bu eğitime yönelik eleştiriler açısından ele alınmasından sonra (s. 115-137); üçüncü bölümde konunun tartışılmaya açıldığı özel bağlam, ortaöğretim din kültürü ve ahlak bilgisi ders kitaplarında çoğulculuk olgusunun ne şekilde gerçekleştiğidir ( s. 139-279). Bunun için öncelikle kitaplardaki politik çoğulculuk incelenmiştir. Daha sonra sosyo-kültürel çoğulculuk, son olarak da konunun odak noktası olan dini çoğulculuk ele alınmıştır. Üçüncü bölüm; esasen eserde kullanılan nitel yöntemin hangi açılardan ve nasıl işe koşulduğunu gösteren kısımdır (s.139-

2 Robert Jackson, Din Eğitimi: Yorumlayııı Bir Yaklaşım, çev. , Üzeyir Ok, M. Ali Özkan (İstanbul: DEM Yayınları, 2005).

3 Robert Jackson, Religious Education: An Interpretive Approach (London: Hodder and Stoughton, 1997).

Sakarya Üniversitesi İlahiyat Fakültesi Dergisi (SAUIFD), Cilt: XIX, Sayı: 36 (Aralık 2017) 
279). Eserde, örnek olarak seçilen din dersi kitaplarının dini çoğulculuğu barındırıp barındırmadığının test edilmesi kitabın bu bölümündeki yöntemlerle sınanmıştır. Bu amaçla öncelikle çoğulculuk daha önce yapılan tanımına uygun olarak, politik, sosyo-kültürel ve dini çoğulculuk bakımından kategorize edilmiştir. Daha sonra her bir çoğulculuk çeşidinin ortaöğretim din dersi kitaplarında ne şekilde ele alındığını tespiti için din eğitimden nitel bir araştırma yöntemi olan Nvivo 10 programı kullanılmıştır. Her bir çoğulculuk çeşidini temsil eden alt kavramlar belirlenmiştir. Daha sonra kavramların ders kitaplarında sorgulanmasına geçilmiştir. Son olarak da Nvivo 10 programının çıktıları çoğulculuk bağlamında tartışılmıştır.

Üçüncü bölümde işe koşulan alt kavramlar ve bunların çoğulculuk açısından sorgulanmasına örnek olması açısından bazı örnekler vermek gerekirse şunları söyleyebiliriz: Politik çoğulculuk konusunda insan, insana saygı, insanın doğası olarak inanan insan, temel hak ve özgürlükler açısından özgürlüklerin sınırı, inanç özgürlüğü, inancın temellendirilmesi açısından doğru inanç, insanın sorumlu bir varlık olarak yaratılması gibi alt kavramlar incelenmiştir. Sosyo-kültürel çoğulculuk bağlamında kültürün çok amaçlı bir toplumda anlayışında yeri, toplumsal hayatın sürekli akış içinde olması, örf ve adetlerimizin temelinde din duygusunun yer alması, birlikte yaşama açısından çok kültürlülük, bir arada yaşama örnekleri açısından Hz. Muhammed ve Medine Sözleşmesi, tasavvufun toplumsal birleştirici rolü gibi alt konular kitaplarda taranarak sosyo-kültürel çoğulculuğun buradaki varlığı sınanmıştir.

Din dersleri bağlamında asıl ortaya konulmak istenen dini çoğulculuğun ders kitaplarındaki yeri; din içi ve dinler arası farklılıklara bakış ekseninde temelde iki açıdan incelenmiştir. Cari din dersi öğretim programlarının mezhepler üstü ve dinler arası açılımlı olduğu iddiasının bu alt bölümde ders kitapları bağlamında sınanması gerçekleştirilmiş̧ir. Zira 2005 yılında değişen orta öğretim ortaöğretim din dersi programlarının ana iddiası bu yöndedir. Programların adı geçen yaklaşıma ihtiyaç duyması Türkiye'nin AïHM gibi kurumlarda muhatap olduğu din dersiyle ilgili davalardır. Bu davaların özünde "Tek tip bir din eğitiminin her vatandaşa dayatıldığı" iddiası yer almıştır. Bu bakımdan ders kitaplarının ilgili açılardan incelenmesi önemlidir. Ders kitaplarında dini içi çoğulculuk İslam'da farklı görüşler bağlamında s1nanmıştır. Kitapların mezhepler üstü olduğuna yönelik Ehl-i Beyt konusuna yaklaşım örnek gösterilmiştir. Zira Türkiye'de din içi çoğulculuğun ders kitaplarında tesis edilmediğinin en büyük tartışması Alevilik ekseninde yürütülmektedir. Bu meyanda ders kitaplarında Aleviliğin İslam içi bir tasavvufi yorum olarak ele alınması ve Ehl-i Beyt kavramının mezhepler üstü anlatılmaya çalışılması öne çıkmaktadır. Dinler arası çoğulculuk ders kitaplarında, 
dinlerde ortak olan noktaların öne çıkarılması ve diğer inançlarla ilgili yaralayıcı olmayan bir dilin kullanımıyla ve tüm inançların yaşayan din kapsamında ele alınmasıyla tesis edilmeye çalışılmıştır. Kitapların incelenmesinde bu açıkça ortaya çıkmaktadır.

Sonuç ve öneriler kısmı (s.281-294) oldukça önemlidir. Buna göre ortaöğretim din dersi kitaplarında çoğulculuğun genel anlamda tesis edildiği tespit edilmiştir. Ancak ders kitaplarının temel hak ve özgürlüklerle çelişen ifadelerden arındırılmasına dayalı öneriler bu kitapların eksikliği olarak not edilebilir. Özellikle kitapların yazarlarına yönelik yapılan, “ötekileştirici söylemlerden uzak durmaları" uyarıları konunun akademik ortamda dahi henüz yeterince içselleştirilemediğini göstermektedir. Eserde örneklem olarak ortaokul ders kitaplarının da çalışmaya dâhil edilmesi çalışma kapsamında gerçekleştirilebilirdi. Ancak çalışmanın yapıldığı zaman dilimi ve çalışmanın kapsamı buna engel olmuş olabilir. Ayrıca çalışmanın kitap haline gelen boyutu akademik tezin tüm verilerini aktarmadan daha kısa bir kapsama sokularak ortalama bir sosyal bilim okuyucusu da hitap edebilirdi. Zira çoğulcu din eğitimi meselesi, sadece ilahiyatçıların değil; Eğitimde Reform Girişimi (ERG) gibi sivil toplum örgütlerinin de gündeminde olan bir konudur ve farklılıklar bağlamında uzun bir süre daha ülke gündeminde yer alacak gibi durmaktadır. Sonuç olarak denilebilir ki, Cemil Osmanoğlu'nun nitel yöntemleri de işe koşarak gerçekleştirdiği bu çalışması yoğun bir emek mahsulüdür. Türkiye din eğitimi araştırmalarının yönelmesi gereken bir rotaya da işaret etmesi bakımından ayrıca önemlidir. Sadece alanda çalışanlara değil tüm ilgililere kaynak bir eser niteliği taşımaktadır. Eserin teorik kısmı özellikle çok kültürlülük meselesiyle ilgili çalışanlar için önemli bilgileri akademik bir kapsam ve metotla ele alarak teorik düzlemde önemli bir başvuru kaynağı niteliğindedir. 